\title{
Studi Nutrisi Buah Ara (Ficus racemosa L.) untuk Pakan Ikan
}

\author{
Netti Aryani ${ }^{1 *}$, Zuhelmi Zen²), Hafrijal Syandri3), dan Jaswandi2) \\ ${ }^{1 *}$ Program Pascasarjana Universitas Andalas Padang \\ ${ }^{2}$ Fakultas Peternakan, Universitas Andalas, Padang. \\ ${ }^{3}$ Fakultas Perikanan dan IImu Kelautan Universitas Bung Hatta, Padang. \\ Diterima 12/01/09 Disetujui 03/08/09
}

\begin{abstract}
The purpose of the research was to find out the countent of nutrition of Ara (Ficus racemosa $L$ ) wich covers : the level of protein, fat, water, ash, fibrous part of the fruit, calcium, phosphor, vitamine $C$ and $E$ as well as amino acid which are very useful for enrichment of fish diets. The sample of Ara fruit were collected directly in the field. There were two types of processing Ara fruits used in this research, namely (1) cutting the fruits into thin layer and made it into; (2) separating the fuit from the seed, dried, and made it into flour. The level of protein, fat, fibrous part of the fruit, water, and ash was analyzed by using proximate analysis, while the level of calcium was analyzed by using AAS methods. The level of phosphor was measured by using spectrophotometer, the level of vitamine $C$ and $E$ was analyzed by using HPLC and amino acid by gas chromatography (CG). The study found that the flesh flour of Ara fruit contained protein $(10,63 \%)$, fat $(8,66 \%)$, water $(7,08 \%)$, ash $(11,57 \%)$, fibrous part of the fruit $(16,15 \%)$, calcium $514,88 \mathrm{mg} / 100 \mathrm{~g})$, phosphor $(418,29 \mathrm{mg} / 100 \mathrm{~g})$, vitamine C $(475,38 \mathrm{mg} / 100 \mathrm{~g})$, and amino acid $(3,013 \%) \mathrm{higher}$ than Ara flour with protein $(8,98 \%)$, fat $(6,57 \%)$, water $(10,26 \%)$, ash $(18,23 \%)$, fibrous part of the fruit $(20,31 \%)$, calcium $(0,039 \mathrm{mg} / 100 \mathrm{~g})$, phosphor $(0,002 \mathrm{mg} / 100 \mathrm{~g})$, vitamin C 25,48 mg/100 g ), and amino acid (1,24\%). It can be concluded that the Ara flour can be used as on of the ingredients for fish diets especially as the source of vitamine $\mathrm{C}$, calcium and phosphor to incrase reproduction ability and growth.
\end{abstract}

Keyword: Ara fruits, fibrous part of fruits, vitamine $C$ and $E$

\section{PENDAHULUAN}

Di alam, ikan dapat memenuhi kebutuhannya dengan pakan yang tersedia, dalam hal ini ikan mempunyai kesempatan untuk memilih, oleh karena itu pakan yang berasal dari alam selalu sesuai dengan selera ikan. Salah satu sumber makanan ikan yang hidup di Sungai adalah buah Ara. Buah ini mampu memberikan sumber energi bagi ikan untuk mempertahankan kelangsungan hidup dan melakukan proses reproduksi. Dalam lingkungan budidaya, ikan lebih tergantung pada pakan buatan. Pada umunya bahan baku untuk pakan termasuk vitamin diimport dari luar negeri dengan harga yang relatif mahal. Maka perlu alternatif lain pengganti bahan import tersebut yang berbasis sumber daya lokal sehingga biaya produksi pakan menjadi lebih murah. Buah Ara (Ficus racemosa $\mathrm{L}$ ) merupakan salah satu sumberdaya lokal yang berpeluang untuk dimanfaatkan sebagai alternatif sumber nutrien dalam ransum pakan ikan. Buah Ara merupakan famili Moraceae tumbuhan tersebut tumbuh

\footnotetext{
*Telp: 0751-463320, HP.081374705877

Email: netti_aryani@yahoo.com
}

di sepanjang pinggir sungai, di pinggiran sungai Anai, sungai Antokan, sungai Sinamar dan beberapa sungai kecil di Kota Padang dan di pinggir sungai Kampar di Riau, di pinggir sungai Batanghari di jambi.

Buah Ara memiliki ciri khas pada bentuk dan strukturnya yang disebut dengan fig atau syconium. Fig merupakan bunga atau buah semu majemuk yang disusun oleh receptaculum atau dasar bunga bersama yang berdaging dan berair. Bunga atau buah yang sesungguhnya terdapat pada dinding sebelah dalam dari receptaculum tersebut. (Hooker, 1894 dalam Ismanidar, 1998).

Tumbuhan Ara berbuah sepanjang tahun, diperkirakan setiap pohon Ara mempunyai buah segar berkisar $1.000-1.500 \mathrm{~kg}$ per pohon setiap musim dan belum dimanfaatkan (hasil pengamatan penulis di lapangan). Tumbuhan tersebut mempunyai nilai sebagai buah yang bisa dimakan, dijadikan obat dan sebagai tanaman hias. Bahkan beberapa jenis ada yang dijadikan obat secara langsung seperti Ficus variegata, Ficus septica dan Ficus quercifolia untuk mengobati penyakit bisul, borok, luka, diare, eksim dan penawar 
racun binatang berbisa. (Hidayat, 1991). Sedangkan Stenis (1978) menyatakan bahwa ada jenis Ficus yang bisa dijadikan sebagai bahan pakaian dan diambil getahnya sebagai pengganti karet.

Buah Ara yang telah masak apabila jatuh ke sungai dimakan oleh ikan terutama jenis herbivore seperti ikan Jelawat (Leptobarbus hoeveni Blkr) ikan Garing (Tor douronensis Blkr), dan ikan Kalabau (Osteochillus kalabau CV). Kenyataan ini diperkuat oleh pendapat Ridley (1930) bahwa dari sekian banyak jenis Ara (Ficus) yang terdapat di hutan tropis Indonesia, ada beberapa jenis yang dimakan oleh bangsa hewan seperti mamalia, burung dan ikan.Kiat, (2000), melaporkan bahwa buah dari tumbuhan Ficus sp dimakan oleh ikan yang hidup di sungai di Semenanjung Malaysia, yang disebut dengan ikan Mahseer atau sejenis Tor. Dari informasi ini diduga buah Ara mempunyai potensi sebagai sumber nutrien bagi ikan oleh karena itu perlu diketahui kandungan nutrisi buah Ara dengan proses pengolahan yang berbeda sebagai sumber nutrien di dalam ransum pakan ikan.

\section{METODE PENELITIAN}

Tumbuhan Ara yang digunakan diambil dari pinggir Sungai Batang Anai di daerah Pasar Usang Kabupaten Padang Pariaman (Gambar 1-A). Identifikasi sampel dilakukan di Herbarium Universitas Andalas Padang dari bulan Desember 2006 sampai dengan Januari 2007. Untuk keperluan tersebut, digunakan sampel yang telah masak, yang masih muda, putik dan bagian ranting yang berdaun beserta bunganya, kertas koran dan spritus. Ranting dengan buah yang masih muda beserta

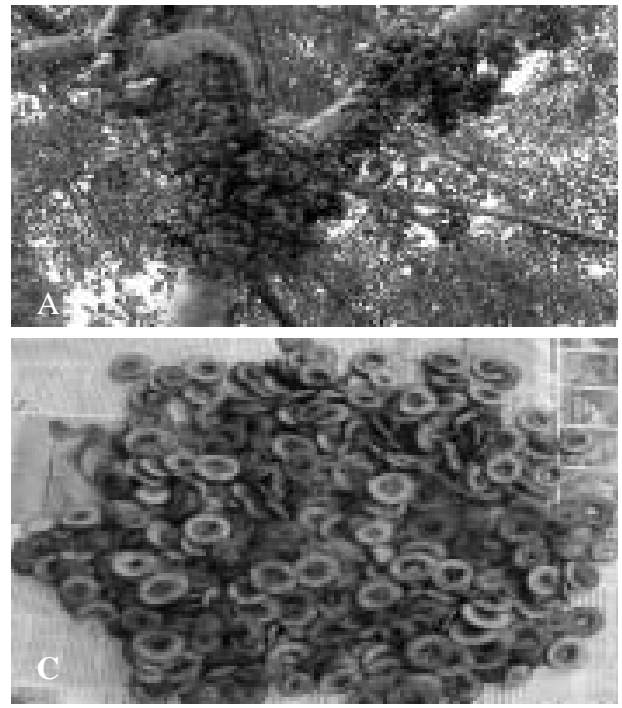

putik dan bunga buah, dibungkus dengan kertas koran, dan disiram dengan spritus hingga merata, kemudian disimpan pada suhu kamar selama tiga harii hingga mengering. Selanjutnya sampel yang telah mengering diletakkan di atas wadah khusus untuk identifikasi dan sampel dikaitkan dengan benang agar tidak terlepas, kemudian dilakukan identifikasi. Deskripsi tanaman buah Ara diidentifikasi berdasarkan Backker dan Van Den Brink (1965) serta Corner \& Watanabe (1969).

Tumbuhan Ara yang digunakan mempunyai ciri sebagai berikut: kedudukan daun pada batang berselang seling, jumLah pertulangan daun antara 6 sampai dengan 7 buah, ujung daun meruncing, pangkal daun membulat, panjang tangkai daun antara 1,25 sampai dengan $6,25 \mathrm{~cm}$. Bentuk daun ellips dengan ukuran panjang 4,3 sampai dengan $9,3 \mathrm{~cm}$ dan lebar 1,5 sampai dengan $4,0 \mathrm{~cm}$. Hasil identifikasi memperlihatkan tumbuhan Ara yang digunakan adalah jenis Ficus racemosa $\mathrm{L}$

Untuk mengetahui kadar nutrisi yang terdapat pada buah Ara dilakukan penelitian dari bulan Januari 2007 sampai dengan April 2007. Koleksi sampel dilakukan dengan cara pengumpulan secara langsung di lapangan. Sampel yang telah masak dan berwarna merah diambil dari pohonnya di pinggir Sungai Anai Sumatera Barat (Gambar 1-B). Sampel dikumpulkan dan dimasukkan ke dalam karung. Proses pengolahan sampel terdiri dari dua tipe yakni 1) sampel secara utuh diiris tipis dan dijemur di bawah sinar matahari selama tiga hari dengan temperatur kurang lebih $60^{\circ} \mathrm{C}$ (Gambar C), 2) sampel hanya dikoleksi daging buahnya saja, kemudian dijemur di bawah sinar matahari dengan
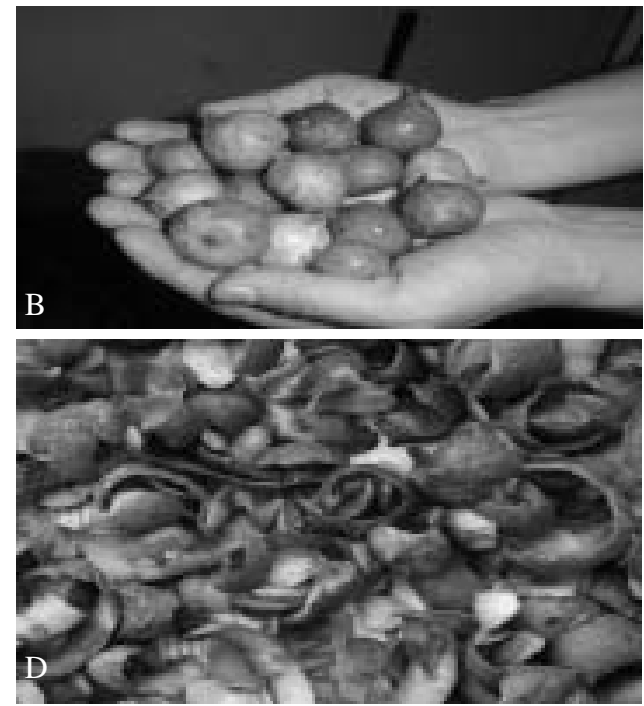

Gambar 1. Pohon Ara yang tumbuh dipinggir sungai $(A)$, buah Ara yang telah masak (B), irisan buah Ara utuh (C) dan irisan daging buah Ara (D) 
temperatur kurang lebih $60^{\circ} \mathrm{C}$ (Gambar D). Setelah kedua sampel kering, dihaluskan dengan menggunakan alat penggiling (blender), tanpa menggunakan ayakan. dan diperoleh tepung buah Ara utuh dan tepung daging buah Ara.

Analisa kadar protein, lemak, serat kasar, kadar air dan kadar abu menggunakan analisis proksimat, diperlukan sampel masing-masing sebanyak 100 gram. Analisa sampel dilakukan di Laboratorium Teknologi Industri Pakan, Fakultas Peternakan Universitas Andalas Padang. Data yang diperoleh dianalisa secara deskriptif

Analisa kadar protein. Dengan menggunakan metode Kjeldahl, melalui 3 tahap yaitu destruksi (pembakaran), destilasi (penyulingan) dan titrasi (penitaran). Tahap destruksi sampel ditimbang sebanyak satu gram (x), dimasukkan ke dalam labu Kejldal, ditambahkan katalisator selenium (Se) dan 25 $\mathrm{mL} \mathrm{H}_{2} \mathrm{SO}_{4}$ pekat, kemudian dicampur rata. Sampel dipanaskan sampai terjadi perubahan warna menjadi bening. Sampel hasil destruksi diencerkan dengan aquades dalam labu ukur $500 \mathrm{~mL} .10 \mathrm{~mL}$ larutan filtrat dimasukkan ke dalam tabung destilasi ditambahkan $25 \mathrm{~mL} \mathrm{NaOH}$ dan $7 \mathrm{~mL}$ aquades dan batu didih. Destilasi ditampung dengan $10 \mathrm{~mL} \mathrm{H}_{2} \mathrm{SO}_{4}$ yang telah ditambahkan 4 tetes indikator metil merah. Destilasi selesai bila terjadi letupan batu didih atau $2 / 3$ cairan tersuling. Tahap titrasi, hasil sulingan di dalam labu erlenmeyer dititrasi dengan $\mathrm{NaOH}$ standar $0,1 \mathrm{~N}(\mathrm{z})$ hingga berubah warna. Dilakukan juga untuk Blanko $25 \mathrm{~mL} \mathrm{H}_{2} \mathrm{SO}_{4} \quad 0,05 \mathrm{~N}$ tambah 3 tetes indikator metil merah, lalu dititer dengan $\mathrm{NaOH} 0,1 \mathrm{~N}$ (y) Kadar protein dihitung dengan menggunkan rumus:

$$
\operatorname{protein}(\%)=\frac{(y-z) \times N \times 0,014 \times 6,25}{x} \times 100 \%
$$

\section{Keterangan :}

$\mathrm{z}=$ jumLah $\mathrm{NaOH}$ penitaran sampel

$\mathrm{y}=$ JumLah $\mathrm{NaOH}$ penitaran blanko

$\mathrm{X}=$ berat sampel

$\mathrm{N}=$ normalitet $\mathrm{NaOH}$ yang dipakai.

Analisis kadar lemak. Dengan menggunakan metode Soxhlet (AOAC, 1995). Sampel ditimbang sebanyak satu gram $(A)$ kemudian dibungkus dengan menggunakan kertas lemak, dikeringkan dalam oven listrik selama 12 jam pada temperatur $105^{\circ} \mathrm{C}$. Sampel ditimbang dalam keadaan panas $\left(\mathrm{X}_{1}\right)$ berikutnya dilakukan ekstraksi dengan benzena dalam soxhlet sampai benzena jernih. Kemudian sampel dikeringkan dalam oven listrik selama empat jam dengan temperatur $105^{\circ} \mathrm{C}$, selanjutnya ditimbang, $\left(X_{2}\right)$, dan dihitung dengan menggunakan rumus:

$$
\text { kadar lemak }(\%)=\frac{\left(X_{1}-X_{2}\right)}{A} \times 100 \%
$$

Keterangan:

$\mathrm{X}_{1}=$ berat sampel setelah proses ekstraksi

$\mathrm{X}_{2}=$ berat sampel sebelum proses ekstraksi

$A=$ berat sampel

Analisa kadar abu. Cawan porselin yang akan digunakan ditimbang kemudian diovenkan selama satu jam dengan temperatur $110^{\circ} \mathrm{C}$ dan didinginkan lalu ditimbang beratnya (A) Selanjutnya sampel ditimbang sebanyak satu gram, cawan yang berisi sampel (B) dipanaskan dalam tanur pada temperatur $600^{\circ} \mathrm{C}$ selama empat jam dan didinginkan selama dua jam. Berikut sampel diovenkan pada temperatur $110^{\circ} \mathrm{C}$ selama satu jam, sampel didinginkan dan ditimbang kembali (C). Kadar abu dihitung dengan rumus banyaknya abu yang tersisa setelah pembakaran yaitu dengan cara mengukur selisih antara berat cawan akhir (cawan berisi bsampel setelah dibakar dalam tanur) dengan cawan awal (cawan kosong tanpa sampel dibandingkan dengan berat sampel, dengan rumus :

Keterangan :

kadar abu $(\%)=\frac{(C-A)}{(B-A)} \times 100 \%$

$A=$ berat cawan

$\mathrm{B}=$ berat sampel

$\mathrm{C}=$ berat sampel setelah ditanur

Analisa kadar air. Cawan porselin diovenkan dengan temperatur $110^{\circ} \mathrm{C}$ selama satu jam, dan ditimbang (A), sampel sebanyak satu gram (B) dimasukkan ke dalam cawan dan dipanaskan di oven dengan temperatur $110^{\circ} \mathrm{C}$ selama dua jam, pindahkan ke desikator, dinginkan selama 30 menit. Kemudian cawan ditimbang, selanjutnya panaskan kembali cawan berisi sampel selama satu jam hingga beratnya tetap (C) Kadar air ditentukan banyaknya air yang menguap saat pemanasan, yaitu dengan cara mengukur selisih antara berat cawan akhir (setelah cawan berisi sampel dikeringkan dalam oven) dengan berat cawan awal 
(cawan kosong bebas air), dibandingkan dengan berat sampel, dengan perhitungan sebagai berikut:

$$
\text { kadar air (\%) }=\frac{B-A}{B-C} \times 100 \%
$$

Keterangan:

$$
\begin{aligned}
& A=\text { berat cawan } \\
& B=\text { berat sampel } \\
& C=\text { berat cawan dan sampel } \\
& \text { penimbangan terakhir }
\end{aligned}
$$

Analisa kadar serat kasar. Dengan menggunakan metode (AOAC, 1995), yaitu dengan cara melarutkan satu gram $(\mathrm{x})$ sampel ke dalam gelas piala $600 \mathrm{~mL}$, kemudian ditambahkan $40 \mathrm{~mL} \mathrm{H}_{2} \mathrm{SO}_{4} 0,3 \mathrm{~N}$ dan panaskan selama 30 menit., kemudian tambahkan $25 \mathrm{~mL} \mathrm{NaOH}$ 1,5 $\mathrm{N}$ dan di masak selama 30menit. Selanjutnya sampel disaring dengan kertas saring yang telah diketahui beratnya(a) berikut dimasukkan ke dalam cawan buncher. Penyaringan dilakukan dengan labu pengisap yang dihubungkan dengan pompa vakum. Selama penyaringan endapan dicuci berturut-turut dengan $50 \mathrm{~mL}$ aquades panas, $50 \mathrm{~mL} \mathrm{H}_{2} \mathrm{SO}_{4} 0,3 \mathrm{~N}$, dan $25 \mathrm{~mL}$ aseton. Kertas saring yang berisi sampel dimasukkan kedalam cawan porselin dan dikeringkan selama 1 jam dalam oven pada temperatur $105^{\circ} \mathrm{C}$, kemudian didinginkan di dalam desikator dan ditimbang (b), diabukan dalam tanur listrik pada temperatur $600^{\circ} \mathrm{C}$ selama empat jam hingga menjadi abu putih. Sampel didinginkan dalam desikator dan ditimbang (c), kadar serat kasar dihitung dengan menggunakan rumus:

$$
\text { serat kasar }(\%)=\frac{b-c-a}{x} \times 100 \%
$$

Keterangan :

$\mathrm{b}=$ berat cawan hasil saringan $\mathrm{c}=$ cawan dan sampel setelah ditanur

$\mathrm{a}=$ berat kertas saring

$\mathrm{x}=$ berat sampel

Analisa kadar kalsium dilakukan dengan metode AAS, phospor dengan spectrophotometer, vitamin C dan E dengan alat HPLC (menurut metode Scuep et al., 1994) serta asam amino dengan metode Gas Chromatography (CG) dilakukan di Laboratorium P.T Saraswanti Indo Genetech, Bogor menggunakan sampel masing-masing sebanyak $300 \mathrm{~g}$. Data yang diperoleh dianalisa secara deskriptif

\section{HASIL DAN PEMBAHASAN}

Hasil penelitian memperlihatkan bahwa antara tepung buah $\mathrm{Ara}^{1)}$ dan tepung daging buah $\mathrm{Ara}^{2)}$ dengan dua tipe pengolahan yang berbeda terbukti mengandung kadar nutrisi yang berbeda pula (Tabel 1). Buah Ara yang diolah secara keseluruhan tepungnya mengandung kadar protein masing-masing sebesar 8,98\%, lemak 6,57\%, kadar air 10,26\%, kadar abu $18,23 \%$, serat kasar $20,31 \%$, kalsium $0,039 \%$, phospor $0,002 \%$ dan vitamin C 25,48 mg/100 g dan vitamin $\mathrm{E}$ $1,64 \mathrm{mg} / 100 \mathrm{~g}$. Sedangkan tepung daging buah Ara mengandung kadar protein masing-masing sebesar 10,63\%, lemak 8,66\%, kadar air 7,08\%, kadar abu $7,08 \%$, kalsium $514,88 \%$, phospor $418,29 \%$, vitamin C $475,28 \mathrm{mg} / 100 \mathrm{~g}$, dan vitamin E 2,87 mg/ 100g, dalam keadaan segar kadar vitamin C buah Ara $45,58 \mathrm{mg} / 100 \mathrm{~g}$. Dengan demikian tepung daging buah Ara mengandung vitamin $\mathrm{C}$ lebih besar daripada tepung buah Ara dan buah Ara dalam keadaan segar.

Tepung daging buah Ara diduga dapat dimanfaatkan sebagai sumber vitamin $\mathrm{C}$ dan mineral terutama kalsium dan phospor di dalam pakan ikan. Serat kasar pada tepung daging buah lebih rendah jika dibandingkan dengan tepung buah Ara utuh hal ini

Tabel 1. Kandungan nutrisi tepung Buah Ara dan daging Buah Ara

\begin{tabular}{clcc}
\hline \multirow{2}{*}{ No } & \multicolumn{2}{c}{ Parameter } & \multicolumn{2}{c}{ Hasil Analisis } \\
\cline { 3 - 4 } & & kadar protein (\%) & Tepung daging buah ara ${ }^{2)}$ \\
2 & kadar lemak (\%) & 8,98 & 10,63 \\
3 & kadar air (\%) & 6,57 & 8,66 \\
4 & kadar abu (\%) & 10,26 & 7,08 \\
5 & serat kasar (\%) & 18,23 & 11,57 \\
6 & kalsium (mg/100g) & 20,31 & 16,15 \\
7 & phospor (mg/100g) & 0,039 & 514,88 \\
8 & magnesium (mg/100g) & 0,002 & 418,29 \\
9 & vitamin C (mg/100g) & 0,005 & 1,10 \\
10 & vitamin E (mg/100g) & 25,48 & 475,28 \\
\hline
\end{tabular}

Keterangan : ${ }^{1)}$ tepung buah ara yaitu semua komponen buah dianalisis

2). daging buah ara yaitu bagian daging buah yang dianalisis 
disebabkan bagian tengah (biji buah Ara) pada saat pengolahan tidak digunakan, biji buah ara menyebabkan kadar serat kasar pada tepung buah Ara menjadi tinggi, sehingga kadar vitamin $\mathrm{C}$ menjadi rendah. Sebaliknya pada pengolahan tepung daging buah Ara komponen bijinya tidak digunakan sehingga vitamin $\mathrm{C}$ pada daging buah Ara lebih tinggi jika dibandingkan dengan tepung buah Ara utuh.

Morton (1987) menyatakan setiap 100g buah Ficus carica segar mengandung vitamin $\mathrm{C}$ antara 12,2-17,7 mg, kalsium 35-78,2 mg dan phosphor 22-32,9 mg. Tetapi apabila dikeringkan kadar vitamin $\mathrm{C}$ buah ini menjadi nol mg, kadar calcium dan phospor masingmasing $126 \mathrm{mg}$ dan $77 \mathrm{mg}$ serta protein sebesar 4,3 mg. Buah ini dikonsumsi oleh manusia dan diolah dalam bentuk selai, manisan dan sirup. Bila dibandingkan kandungan nutrisi yang terdapat pada tepung daging buah Ara (Ficus racemosa L) lebih tinggi daripada Ficus carica terutama kadar vitamin $\mathrm{C}$, protein, kalsium dan phosphor, perbedaaan kadar nutrisi ini disebabkan karena perbedaan species dari buah Ara. Dari keterangan masyarakat di Sumatera Barat buah Ara yang belum masak juga dikonsumsi manusia sebagai bahan pencampur sambal karena rasanya yang asam.

Berdasarkan pengamatan yang dilakukan di lapangan buah Ara merupakan salah jenis makanan ikan yang hidup di sungai dan berfungsi sebagai sumber vitamin $\mathrm{C}$ yang dapat memicu proses kematangan gonad ikan, sehingga ikan mampu melakukan proses reproduksi dan menghasilkan daya tetas yang lebih baik. Hal ini diperkuat oleh pendapat Agrawal dan Mahajan (1980) bahwa kandungan vitamin C yang terdapat pada darah ikan karper India yang ditangkap di alam mencapai titik terendah saat musim pemijahan yaitu antara $17,95-19,65 \mu \mathrm{g} / \mathrm{mL}$ dan saat pertumbuhan ovarium kadar vitamin C mencapai kisaran 20,39$25,95 \mu \mathrm{g} / \mathrm{mL}$. Kemudian disimpulkan pula bahwa ada mobilisasi vitamin $\mathrm{C}$ yang diperoleh dari pakan alami ke ovarium saat siklus reproduksi. Sandnes et al., (1984) juga melaporkan bahwa telur-telur ikan rainbouw trout yang diperoleh dari alam mengandung vitamin $C$ antara $50-100 \mu \mathrm{g} / \mathrm{g}$, dan mempunyai daya tetas yang lebih baik.

Mineral merupakan elemen anorganik yang dibutuhkan oleh ikan dalam pembentukan jaringan dan berbagai fungsi metabolisme dan osmoregulasi. Mineral dibutuhkan dalam jumLah yang relatif kecil, namun berperan sangat penting dalam menjaga kelangsungan hidup, mengingat beberapa proses yang berlangsung di dalam tubuh ikan membutuhkan mineral. Dari hasil penelitian yang telah dilakukan tepung daging buah Ara juga dapat digunakan sebagai sumber mineral terutama kalsium dan phospor. Fungsi utama kalsium dan phospor pada ikan adalah pada proses pembentuk rangka, yang berperan dalam pembentukan struktur tubuh, seperti tulang, gigi dan sisik ikan. Apabila terjadi defisiensi phospor di dalam pakan buatan maka akan mengakibatkan tulang belakang bengkok dan rapuh.

Tabel 2. Jenis dan kadar asam amino pada Tepung Buah Ara dan Tepung Daging Buah Ara

\begin{tabular}{|c|c|c|c|}
\hline No & Jenis asam amino & $\begin{array}{c}\text { Kadar asam amino } \\
\text { Tepung Buah Ara }(\%)^{1)}\end{array}$ & $\begin{array}{c}\text { Kadar asam amino } \\
\text { Tepung Daging Buah Ara }(\%)^{2)}\end{array}$ \\
\hline 1 & Asam Aspartat & 0,105 & 0,223 \\
\hline 2 & Asam Glutamat & 0,329 & 0,420 \\
\hline 3 & Serin & 0,129 & 0,131 \\
\hline 4 & Glisin & 0,088 & 0,057 \\
\hline 5 & Histidin & 0,061 & 0,198 \\
\hline 6 & Arginin & 0,032 & 0,181 \\
\hline 7 & Threonin & 0,085 & 0,186 \\
\hline 8 & Alanin & 0,00 & 0,119 \\
\hline 9 & Prolin & 0,080 & 0,106 \\
\hline 10 & Tirosin & 0,041 & 0,106 \\
\hline 11 & Valin & 0,047 & 0,223 \\
\hline 12 & Methionin & 0,038 & 0,222 \\
\hline 13 & Sistin & 0,033 & 0,076 \\
\hline 14 & Isoleusin & 0,034 & 0,0157 \\
\hline 15 & Leusin & 0,029 & 0,287 \\
\hline 16 & Phenilalanin & 0,016 & 0,109 \\
\hline 17 & Lisin & 0,088 & 0,212 \\
\hline \multicolumn{2}{|c|}{ Total asam amino } & 1,235 & 3,013 \\
\hline \multicolumn{2}{|c|}{ Total protein } & 8,98 & 10,63 \\
\hline
\end{tabular}

Keterangan: ${ }^{1)}$ tepung buah ara yaitu semua komponen buah dianalisis

2) daging buah ara yaitu bagian daging yang dianalisis 
Agar tidak terjadi defisiensi kalsium dan phospor di dalam pakan maka perlu diberikan sebanyak 3-5 g/kg pakan (Zoonneveld et al., 1991).

Kualitas protein pakan ditentukan oleh kandungan asam aminonya, terutama yang tidak dapat disediakan oleh tubuh, sehingga harus ditambahkan ke dalam ransum pakan. Hasil analisis jenis dan kadar asam amino tepung buah Ara dan tepung daging buah Ara (Tabel 2) memperlihatkan total asam amino tepung buah Ara $(1,235 \%)$ lebih kecil bila dibandingkan dengan total asam amino tepung daging buah Ara (3,013\%), demikian juga halnya dengan kadar asam amino yang terkandung di dalamnnya. Dari 17 jenis asam amino yang terdapat pada tepung daging buah Ara, terdapat 9 jenis asam amino essensial dan 8 jenis non essensial. Sedangkan asam amino essensial yang tidak terdapat yakni triptopan. Walaupun kadar protein tepung daging buah Ara sebesar 10,63\%, akan tetapi memiliki jenis asam amino essensial yang mendekati sempurna dan dapat melengkapi kekurangan jumLah dan jenis asam amino yang terdapat pada bahan pakan lain.

Kebutuhan setiap jenis ikan terhadap asam amino essensial dan non essensial berbeda-beda, sehingga diperlukan keseimbangan antara asam amino essensial dan non essensial yang terkandung pada bahan dasar pakan ikan. Tepung daging buah Ara dapat melengkapi defisiensi jenis asam amino pada bahan pakan ikan, karena sumber protein yang berasal dari kacangkacangan mengalami defisiensi asam amino essensial metionin dan non essensial sistin, namun kaya akan lisin, maka dengan pemakaian tepung daging buah Ara dapat melengkapi kekurangan metionin yang terdapat di dalam pakan lain, sehingga kebutuhan ikan terhadap asam amino essensial dapat dipenuhi. Hasil penelitian pendahuluan penulis tepung telur induk ikan Jelawat mengandung metionin $1,41 \%$ dan lisin $4,64 \%$, berarti induk ikan Jelawat membutuhkan asam amino lisin dan metionin yang cukup besar di dalam pakannya dan tepung daging buah Ara dapat memberikan kontribusi kedua jenis asam amino tersebut.

Hidayat (1991) menyatakan bahwa beberapa tanaman Ficus menghasilkan bahan-bahan kimia tertentu seperti polifenol, alkaloid, flavanoid, saponin dan tanin. Dari hasil penelitian Achmad et al., (2001) diketahui species Artocarpus yang berasal dari tanaman famili Moraceae mengandung senyawa beracun yang sangat manjur untuk mengobati sel tumor pada manusia. Kemudian Rajib et al., (2004) melaporkan bahwa tumbuhan jenis Ficus hispida dapat menurunkan kadar glucosa di dalam darah dan dapat meningkatkan proses glycogenesis. Selanjutnya Li et al., (2004) dari hasil penelitiannya menyatakan bahwa jenis Ficus racemosa dapat berfungsi sebagai anti inflammatory.Yelmida (2005) melaporkan pula tumbuhan famili Moraceae mengandung senyawa aromatik sebagai komponen utamanya, dan senyawa non aromatik seperti terpenoid, steroid, alkaloid piperin, asam lemak, dan asam amino, tetapi tidak dijelaskan jenis asam aminonya.

Dari laporan beberapa peneliti tersebut, pemanfaatan tumbuhan Ara (Ficus sp) lebih ditujukan pada aspek farmakologi mulai dari bagian batang, kulit, ranting dan daun. Berdasarkan kajian ini maka tepung daging buah Ara dapat digunakan di dalam ransum pakan terutama sebagai sumber vitamin $\mathrm{C}$, kalsium dan phospor, serta sedang dikaji respon biologinya untuk reproduksi ikan.

\section{KESIMPULAN}

Kadar nutrisi tepung daging buah Ara terutama protein $(10,63 \%)$, kalsium, $(514,88 \mathrm{mg} / 100 \mathrm{~g})$, phospor $(418,29 \mathrm{mg} / 100 \mathrm{~g})$, vitamin C $(475,28 \mathrm{mg} / 100 \mathrm{~g})$, dan total asam amino $(3,013 \%)$ lebih tinggi dibandingkan dengan tepung buah Ara protein (8,98\%), kalsium (0,039 $\mathrm{mg} / 100 \mathrm{~g})$, phospor $(0,002 \mathrm{mg} / 100 \mathrm{~g})$, vitamin C $(25,48$ $\mathrm{mg} / 100 \mathrm{~g})$, dan total asam amino (1,24\%). Nutrisi tersebut mempunyai peluang untuk dimanfaatkan sebagai bahan pengayaan ransum pakan terutama sebagai sumber vitamin $\mathrm{C}$, kalsium dan phospor untuk memicu perkembangan gonad induk ikan dan pertumbuhan benih.

\section{UCAPAN TERIMA KASIH}

Terima kasih disampaikan berbagai pihal yang telah bersedia meluangkan waktu untuk memberi saran dan masukan selama melakukan penelitian dan penulisan artikel ini.

\section{DAFTAR PUSTAKA}

Achmad, S.A, Hakim, E.H., Makmur, L., Mujahidin, D., \& Syah, Y.M. 2001. Natural Products chemistry for a better understanding of biodiversity: Flavonoids in Moraceae as a case study. Jurnal Kimia Andalas II 7: 6-11

AOAC, 1995. Official methods of analysis 16 th ed. Association of the official Analitical Chemist. Washington D.C.: Benyamin Franklin. 
Agrawal, N.K. \& Mahajan, C.L. 1980. Comparative tissue ascorbic acid studies in fishes. J. Fish Biol. 17: 135-141.

Backer, C.A \& Van Den Brink, B. 1965. Flora Of Java. Vol II. Angiospermae. Amsterdam: N.V.P Noordhoff Groningen The Nedherlands.

Buwono, D. I., 2000. Kebutuhan Asam Amino Essensial dalam Ransum Ikan. Yogyakarta: Kanisius.

Corner, E.J.H \& Watanabe, T. 1969. Collection Of Illustrated Tropical Plants. Kyoto: Kyoto Univ.

Ismanidar, 1998. Jenis-jenis Ficus di Kotamadya Padang. Skripsi Sarjana Biologi. Fakultas Matematika dan IImu Pengetahuan Alam. Padang: Universitas Andalas.

Kiat, Ng.C. 2004. Kings of the rivers Mahseer in Malaysia and the Region. Inter Sea Fishery (M) Sdn Bhd. Selangor, Darul Ehsan.

Li, R.W, Leach, D.N., Myers, S.P., Lin, G. D., Leach, G.J., \& Waterman, P.G., 2004. A New Anti-Inflammatory Glucoside From Ficus Racemosa. Planta Med 70(5): 421-427.

Morton, J. F. 1987. Ficus carica. Di dalam: Fruits of warm climates. Ficus composisi.

Rajib, G., Sharatchandra, Kh., Rita, S., \& Thokchom, I.S. 2004. Hypoglycemic Activity of Ficus hispida (bark). Di dalam: Normal and Diabetic Albino Rats. Research Paper 36(4): 222-225.

Ridley, H.N. 1930. The dispersal of Plant Throughout the world. L. Reeve \& Co. Ltd. Ashford.

Sandnes, K., Julshamn, K., \& Braekkan, O.R. 1984. Interrelationship betwen ascorbic acid and trace elements in ovarian development in fish. In Ascorbic acid Di dalam: Wegger, J., Tagwerker, F.J., \& Montsgaard, J. (eds.). Domestic Animals. Royal Danish Agric. Soc. Copenhagen. Halaman 213-217.

Stenis, C.G.J. 1978. Flora. Jakarta: PT. Prandnya Paramita.

Watanabe, T. 1988. Vitamin. Di dalam: T. Watanabe (ed.). Fish Nutrition and mariculture. Kanazawa International Fisheries Center, Japan International Cooperation Center. Halaman 7173.

Yelmida. 2005. Senyawa Flavonoid Dari Daun Morus macroura Miq Tumbuhan Langka Di Indonesia. Jurnal Kimia Andalas II 1: $45-48$.

Zonneveld, N., Huisman, E.A., \& J.H. Boon. 1991. PrinsipPrinsip Budidaya Ikan. Jakarta: PT Gramedia Pustaka Utama. 